\title{
Development of International Relations at the Periphery: The Case of Bangladesh
}

\author{
L. Yasmin \\ University of Dhaka, Dhaka, Bangladesh
}

\begin{abstract}
International Relations (IR) is no longer considered as an academic discipline that analyzes the major powers or great powers' activities only. From its Cold War content of emphasizing on traditional state-centric security, it has traversed a long way to expand its subject matter. Similarly, smaller nations and their imprints on international politics are also emerging as a significant area of inquiry in IR. This article seeks to contribute to this inquiry by discussing Bangladesh's rising significance and how academic IR addresses this issue. It traces the history of IR in Bangladesh as well as its gradual expansion. It discusses the growth of IR as an academic discipline at the University of Dhaka, Bangladesh, that gradually led to the development of IR studies in other parts of the country. The article documents this growth, which is the first of its kind to trace the rise and development of IR in Bangladesh. It therefore fulfils the lacuna in understanding how and where the growth of IR took place in a non-western country. One might contend what is the relevance of studying IR in Bangladesh. The article argues that despite being physically small, academic IR has generated interest in Bangladesh due to the changing geostrategic significance of the country. The article outlines the rising geopolitical significance of Bangladesh where great powers are interested to come and be a part of Bangladesh's development. It is in this context, the study of IR becomes more pertinent in Bangladesh.
\end{abstract}

Key words: international relations, Bangladesh, IR studies, geostrategic vision, universities of Bangladesh

The discipline of International Relations (IR) is a product of a specific time and place. The end of the First World War led to the rising concern on having a distinct discipline that would be able to explain causes of war and research on how to prevent it. The foundational principles have been statecentric concern for security, which was reinforced after the onset of the Cold War at the immediate aftermath of the Second World War. The end of the Cold War ushered a shift from a state-centric approach to recognizing non-state threats to security. This led to the unfolding of ontological questions in IR as well by challenging its Western origin as an academic discipline. Gradually scholars from around the world started to initiate and participate in the discussion of non-Western contribution to the discipline. Although this discussion was initially spearheaded from an avowedly Western context that is from Europe and the United States (US) - nonWestern IR established itself as a significant area of inquiry where IR does not only speak about the concerns of the West but also that of "the Rest".

In this article, I inquire the development of IR from Bangladesh's perspective. One may argue what type contribution a country like Bangladesh - small in geographic size and its location predetermines its inability to rise as a Great Power, among other predicaments - would have for IR to learn about the development of IR in the country. This is precisely the opposite of what I advance as my argument that in the time of irreversible globalization and connectivity, IR scholarship must pay attention to its peripheral participants as well - who might look like "peripheral" in traditional context but are "rising" in regional context and can have, in turn, significant influence on international politics.

A nation of 48 years of existence, Bangladesh is the only country that emerged out of a violent conflict during the Cold War period [Buchanan, Moore 2003]. Its War of Independence of 1971 became a unique battle of Cold War politics between the US and former Soviet Union where the Soviet axis, with India firmly supporting Bangladesh's independence while the US, China and Pakistan opposing it. Bangladesh inherited the University of Dhaka, established in 1921, by virtue of which also inherited the very first academic discipline of International Relations established in undivided South Asia in July 1947. Since then, the study of IR in Bangladesh has traversed a long way. Not only the study of IR expanded in the country, but Bangladesh has also acquired a positive recognition in regi- 
onal and international politics which makes it a significant stakeholder in preserving international peace and security.

This article intends to analyze the development of IR in Bangladesh in two broad sections. First, it seeks to find the answer to the question why do we study IR in Bangladesh. In other words, it discusses the rising significance of Bangladesh that makes the study of academic IR appealing, which has contributed to the expansion of IR. In the second section, the article focuses on the academic development of IR in the country as well trends in research in Bangladesh. The article traces the academic history of IR as well as explores how it is flourishing in Bangladesh. The trends in research highlight the immediate and long-term issues that impinge on Bangladesh's security and stability. It is in this context, the article concludes how the rising significance of Bangladesh is leading to both academic as well as non-academic discussions in Bangladesh on international relations.

\section{A Rising Bangladesh: Increasing Geostrategic Significance}

With $147,570 \mathrm{~km}^{2}$, Bangladesh is a small South Asian nation wedged between India on its three sides and Myanmar on the other. As pointed out earlier in this paper, Bangladesh has generally been depicted as a "small" or "weak" nation due to this locational compulsion [Choudhury 1992], which has made it India-locked - or the presence of India as a significant actor in Bangladesh's foreign policy endeavors [Hassan 1989]. Bangladesh's impoverished condition did not escape being noticed internationally when immediately at the aftermath of its birth, American policymakers identified Bangladesh as an "international basket case" [Jahan 1972]. Thus, essentially, for Bangladesh, the first few decades of its emergence were the times to reconstruct and rebuild. Therefore, it did not hesitate to cultivate friendship going beyond its Indo-Soviet axis which was instrumental in achieving independence. Soon, Bangladesh looked towards more potent sources to diversify its need for foreign aid [Yasmin 2016] gradually, the United States and the Arab World came to respond to Bangladesh's need.

Bangladesh in the second decade of 21st century is a different Bangladesh. It is no longer a foreign aid-dependent country where foreign aid constitutes only $2 \%$ of its gross development product (GDP).
Bangladesh is considered as one of the five fastest economies of 2019 by the World Bank (WB) and the International Monetary Fund (IMF) ${ }^{1}$. The terms "Bangladesh conundrum" [Mahmud, Ahmed, Mahajan 2008] and "Bangladesh surprise" [Asadullah, Savoia, Mahmud 2014] are in vogue since the first decade of 2000. The Economist calling Bangladesh "the most intriguing puzzles in development" argues - Bangladesh is no longer a basket case ${ }^{2}$. The social and economic developments that have taken place in Bangladesh for more than a decade now. The country is at the verge of graduating from a "lower middle income country", classified as such by the World Bank to a "developing country" in 2024. Amidst such developments, Bangladesh's geostrategic significance is also on the rise.

While Bangladesh's size, locational reality of being compressed between India and Myanmar and the overwhelming presence of its giant neighbor India curtailed much of foreign policy independence in the past, changes in this regard are abound. Bangladesh has found a third neighbor - an area that has traditionally remained less significant in Bangladesh's policy circles. The long standing conflict in determining maritime boundary between Bangladesh and Myanmar and Bangladesh and India finally has provided Bangladesh with much needed unhindered access in the Bay of Bengal. This has deepened Bangladesh's geostrategic significance which was reverberated in the proclamation of policy makers who work on South Asian region. The much-quoted statement of US Principal Deputy Assistant Secretary Tom Kelly in 2014 [Imam 2014] stands as a key to understanding Bangladesh's rising significance to the US and American ally in the Asia-Pacific region, Japan in countering China's influence in the Bay of Bengal and subsequently in the Indian Ocean region. As Kelly identified Bangladesh as a key player in the Indo-Pacific corridor, now Bangladesh's place in the US proposed Free and Open Indo-Pacific similarly identifies Bangladesh as a "key" player [Miller 2019]. The US commenced its security dialogue with Bangladesh since 2012, a move later on also taken up by the United Kingdom since 2017.

\footnotetext{
1 See: Byron R.K. Bangladesh Second Fastest Growing Economy: IMF // The Daily Star. April 11, 2019.

2 See: Bangladesh: Out of the Basket // The Economist. November 3, 2012.
} 
Bangladesh holds a key place in China's grand design of Belt and Road Initiatives (BRI). China has emerged into not only Bangladesh's largest trading partner since 2005 [Sahoo 2013], but also one of the largest partners in its development initiatives. With loan and investments plans totaling to USD 39.02 billion committed in $2016^{3}$, China - Bangladesh relations soon evolved to a comprehensive strategic partnership, shedding the clouds of China's role towards Bangladesh in early 1970s.

The increasing Chinese interest in Bangladesh has not gone unnoticed by other countries, which have made them to court Bangladesh in a manner that has not been seen in the past. Bangladesh has seen an increasing involvement of great powers in the second decade of 21 st century, where Russia vows to come back to Bangladesh for "a long time" and "seriously", with Japan identifying Bangladesh at the lynchpin position at the mouth of the Bay of Bengal [Yasmin 2016]. Japan provided Bangladesh with the largest sum of overseas development aid (ODA) in 2016 till date and also initiated the Bay of Bengal Industrial Growth Belt (BIG-B) to explore the potentials of the Bay of Bengal region. Moreover, Japan sees Bangladesh as one of the significant players in FOIP $^{4}$, a concept originally conceptualized by Prime Minister Shinzo Abe in 2007.

The study of strategic rivalry of India and China in South Asia, the Bay of Bengal and the Indian Ocean is a topical issue in contemporary politics [Zaman, Yasmin 2014]. Added with this is the Bangladesh dynamics. A countless number of academic research, newspaper articles and academic writing highlight this issue. Indian policymakers as well as researchers have shown their avid interest in identifying the growing nature of Bangladesh - China relations and its implications for India. Prominent Indian strategist C. Raja Mohan raised cautionary notes as early as in 2014 if India was losing the Bay of Bengal to China through its increasing proactive role in the region [Brewster 2014]. After China made its second highest financial commitment to Bangladesh in South Asia after Pakistan, the concern started to mount. The purchasing and delivering of two Chi-

\footnotetext{
3 See: Mirdha R.U. Deals with China a Turning Point for Bangladesh // The Daily Star. October 17, 2016.

4 See: Karim R. Freedom of the Seas: a Cornerstone of Economic Growth // The Daily Star. February 4, 2018.
}

nese submarines to Bangladesh Navy created yet another round of concern for India while its Maldives debacle certainly showed a steady and advancing Chinese march towards the region [Mishra 2018].

Bangladesh has thus emerged as a significant player in the South Asian region by its own right. In terms of social development, it has advanced more than India and Pakistan. In terms of achieving gender gaps, it is the highest scorer in South Asia and second to Asia, behind the Philippines. Despite being small in terms of physical size and one of the most densely populated countries of the world, Bangladesh has been able to carve its own space in international politics. Bangladesh's contribution in the United Nations (UN) Peacekeeping Operations (UNPKOs) has created a positive image of Bangladesh in maintaining international peace and security [Zaman 2016].

However, being small has its disadvantages in terms of arranging resources to attain particular objectives. Bangladesh lacks having a consistent strategic and foreign policy plans. In other words, while the country has five or ten year development plans to achieve economic goals, it lacks having such targeted goals in the areas of foreign and strategic policies. It was evident during the Rohingya influx of August 2017, when Bangladesh found itself "friendless" despite all the major powers' active interest in Bangladesh. For Bangladesh, it was astonishing to watch Indian Prime Minister making a state visit to Myanmar amidst Myanmarese Army's atrocities towards Rohingyas that led them to flee and come to Bangladesh. Thus, Bangladesh's foreign policy is often identified as proactive rather than being a product of cogent calculations ${ }^{5}$.

\section{Institutional Mapping of IR}

\section{IR as an Academic Discipline}

Bangladesh started off its journey to thinking "international" with one institutional department as it inherited the very first Department of International Relations (DUIR) that was established in University of Dhaka (DU), 1947. The study of IR took some time to flourish in academic sense as the second

5 Personal communication with R.U. Zaman, Chairperson, Department of International Relations, University of Dhaka, Bangladesh. 
Table 1. Academic strengths of Departments of IR throughout Bangladesh

\begin{tabular}{|c|c|c|c|c|c|c|c|c|}
\hline \multirow[t]{2}{*}{ Name of University } & \multirow{2}{*}{$\begin{array}{l}\text { Year of } \\
\text { Establish- } \\
\text { ment }\end{array}$} & \multirow[t]{2}{*}{$\begin{array}{l}\text { Faculty } \\
\text { Strength }\end{array}$} & \multicolumn{2}{|c|}{ Programs } & \multicolumn{2}{|c|}{$\begin{array}{l}\text { Higher Degree } \\
\text { Research }\end{array}$} & \multicolumn{2}{|c|}{$\begin{array}{l}\text { Number } \\
\text { of Students }\end{array}$} \\
\hline & & & Honors & Masters & $\begin{array}{l}\text { Master } \\
\text { of Philo- } \\
\text { sophy } \\
\text { (MPhil) }\end{array}$ & $\begin{array}{l}\text { Doctor } \\
\text { of Philo- } \\
\text { sophy } \\
(\mathrm{PhD})\end{array}$ & Honors & Masters \\
\hline University of Dhaka (DU) & 1947 & 34 & Yes & Yes & Yes & Yes & 410 & 85 \\
\hline $\begin{array}{l}\text { Jahangirnagar University } \\
(\mathrm{JU})\end{array}$ & 1999 & 20 & Yes & Yes & Yes & Yes & 366 & 70 \\
\hline $\begin{array}{l}\text { University of Chittagong } \\
\text { (CU) }\end{array}$ & 2004 & 12 & Yes & Yes & No & No & 400 & 60 \\
\hline University of Rajshahi (RU) & 2014 & 6 & Yes & Yes & No & No & 155 & 29 \\
\hline $\begin{array}{l}\text { Bangladesh University } \\
\text { of Professionals (BUP) }\end{array}$ & 2015 & 21 & Yes & Yes & Yes & Yes & 368 & 69 \\
\hline $\begin{array}{l}\text { Bangabandhu Sheikh Mujibar } \\
\text { Rahman Science and Techno- } \\
\text { logy University (BSMRSTU) }\end{array}$ & 2015 & 8 & Yes & Yes & No & No & 405 & —** \\
\hline
\end{tabular}

*Number of students are approximate numbers of April, 2019.

**Master's program would run after the first honors batch from BSMRSTU graduates.

Source: Information in this table is collected by the author from faculties working in these universities.

Department of International Relations was established much later in 1999 in Jahangirnagar University (JU) at the outskirt of Dhaka. Since then, there are six full-fledged Departments of International Relations in six public universities of Bangladesh. Following is a summary of academic strengths of Departments of IR throughout Bangladesh (Table 1).

DUIR spearheaded the study of IR not only in Bangladesh but also in the Indian subcontinent owing to its colonial origin. Professor Dr. Mahmud Hussain from the Department of History (DU) who was the first Head of DUIR, later founded the Department of International Relations at University of Karachi in 1958. The second Head of the Department, Professor P.C. Chakravarti was one of the pioneers in founding Department of International Relations in Jadavpur University, Kolkata in 1956. DUIR has contributed profoundly in the development of IR in other universities in Bangladesh as well by providing inputs in the development of syllabi and by lending teaching assistance at their formative years.

The country has seen a rising interest in learning international issues which is reflected in expanding the learning of IR for professionals in DUIR as well as at JU. DUIR introduced its Certificate Course in International Relations, a three-month program tailored for professionals to learn issues and theories of IR, in 2003. A rising demand of the program led to its transformation to Post-Graduate Diploma in International Relations (PGDIR) in 2007 and subsequently introducing Professional Masters in International Relations (PMIR) in 2016. The second Department of IR in Bangladesh at JU was pioneered by faculties of History and Government and Politics departments of the same university. Gradually, the Department developed into the second largest a full-fledged Department as well as a prominent center for learning IR in Bangladesh.

The growth of academic learning of IR expanded quite speedily since then. Department of IR was established in two public universities and was taught as part minor in one private university - North South University (NSU) - in the first decade of 2000. In the second decade of 2000, two other public universities established the Department of IR and one private university - Independent University, Bangladesh (IUB) - introduced IR as a major as well as a part of foundation course. Among public universities, BUP is expanding its teaching of IR quite fast as it also offers IR as an undergraduate course for training officers who are enrolled in Bangladesh Military Academy (BMA) long courses, which was effective from 75th long courses commenced in 2014. Seven out of 21 faculties of BUP are stationed at BMA to teach training officers at Bhatiari, Chattogram, where BMA is located. 
The recognition of IR as one of the eight subjects taught in BMA - in fact, the only second subject of social sciences besides Economics certainly shows the increasing significance attached to learning IR in a comprehensive manner in Bangladesh. Outside of the academic IR, emerged a Department of Peace and Conflict Studies (PACS) in DU in 1999, which undertook international issues to teach and research. Founded by a professor of Department of Politics of DU, PACS offers courses on the entire gamut of international relations with special focus on conflict, conflict resolution and peace studies. Thus, one can argue that an atmosphere of learning IR from an academic perspective has increased in Bangladesh in contemporary times.

\section{Research Institutions and Research Activities}

Bangladesh has a number of research institutions that dedicate researches on issues pertaining to international relations. The oldest research institute of the country is Bangladesh Institute of Law and International Affairs (BILIA), which was established jointly by the Ministry of Foreign Affairs (MoFA) and the Ministry of Law in June 1972, making it the first Bangladeshi research institute on both law and international affairs. Since then, the International Affairs wing of BILIA pursues original research in the areas that are relevant to Bangladesh's foreign policy as well as on global issues. It holds seminars and symposiums on contemporary issues, where academics, in-service and retired local and foreign diplomats, journalists and eminent personalities participate. For 2017 and 2018, BILIA emphasized original research on Rohingya influx in Bangladesh since August 26, 2017 as well as on the issue of rising power in international politics and its relevance for Bangladesh. BILIA started publishing its journal since 1994, making it the third journal of Bangladesh on international relations.

The next prominent research institute that focusses on international relations primarily is Bangladesh Institute of International and Strategic Studies (BIISS), which was established in June, 1978 by the Government of Bangladesh (GoB). Since its establishment, BIISS has pioneered research on international relations by publishing BIISS Journal in 1980, which is the first journal of its kind in Bangladesh.
BIISS holds seminars, talks and lecture series where national and international speakers present their research on issues relevant to Bangladesh's foreign policy. The activities of BIISS are varied and much larger than that of BILIA due the former having more secured funding. Both BILIA and BIISS publish books on international relations. BILIA's latest publication is Intelligence, National Security, and Foreign Policy: A South Asian Narrative [Ali Ashraf 2016] while BIISS's latest publication is Changing Global Dynamics: Bangladesh Foreign Policy [Abdur Rahman, Kabir 2018]. BIISS has so far published 40 books concerning international relations while the International Affairs wing of BILIA has published nine books.

Apart from BILIA and BIISS, a number of research institutes have emerged that work on Bangladesh's foreign policy, national security and development related issues. Some of the prominent research think-tanks who work exclusively on international relations are Bangladesh Institute of Peace and Security Studies (BIPSS - established in 2007) and Bangladesh Enterprise Institute (BEI-established in October 2000). These two organizations not only work on traditional security issues but also work on non-traditional security issues as well and have strong regional connections. BIPSS publishes its journal Peace and Security Review on a quarterly basis since 2008 while BEI has introduced its journal since July 2018 biannually. Both of the institutions publish policy papers, monographs and books. There are some other institutions in Bangladesh who work on international relations while their primary focus is on economy and development in Bangladesh. Bangladesh Institute of Development Studies (BIDS), a successor of Pakistan Institute of Development Economics (PIDE) which was established in 1957, is the leading think-tank in Bangladesh on economy and development related issues. Similarly, Center for Policy Dialogue (CPD — established in 1993) another think tank that works on similar areas. A number of other research institutions in Bangladesh works on areas that are related to Bangladesh's foreign policy, foreign relations and challenges emanating from non-traditional security threats. A recent area of focus in research has been towards the Bay of Bengal and the Indian Ocean region, keeping up with the global shift of attention to this region, which is reflected in establishing a third think tank by the GoB 
in January 2018. Known as Bangladesh Institute of Maritime Research and Development (BIMRAD), it has started its journey with Bangladesh Navy as its chief patron, showed its promise by holding an international conference on "Maritime Good Governance and Sustainable Development" in November 2018.

\section{Trends in Research - Writers and Issues}

Bangladeshi scholars started writing on Bangladesh's foreign policy, foreign policy predicaments along with bilateral relations since 1970s in the form of books, book chapters and in journals published inside and outside of Bangladesh. What constituted 'international' for Bangladesh was the traditional concern for a newly born state - simply ensuring its survival. The particular nature of Bangladesh's War of Independence also raised another dilemma the withdrawal of Indian forces from Bangladesh's ground. However, there was no particular research yet carried out on this issue albeit leading daily newspapers analyzing the course of Bangladesh - India relations. Later on with the publication of the first journal on international relations by BIISS, more nuanced and issue specific research started to emerge. Keeping in mind of the global reality in 1980, the very first issue covered four topics on superpower relations, one on military regimes, on changing geopolitics of the Indian Ocean region and Non-Aligned Movement (NAM) ${ }^{9}$.

The second journal on international relations was published by DUIR in 1993 where three topics concentrated on post-Cold War future with one of them focusing on the future of IR, one focusing on Bangladesh's future and the other one focusing on the perspectives of the South ${ }^{10}$. Other articles focused on the US interests in the Asia-Pacific and the nuclear issue in the Korean peninsula. The third journal of international relations was published from BILIA which emphasized on human rights and development issues, environmental issue and Bangladesh's bilateral relations ${ }^{11}$. The Department of IR of JU launched its Journal of International Relations in 2005, making it the fourth journal of its kind in Bangladesh. This

9 See: BIISS Journal. 1980. Vol. 1. No. 1.

10 See: Journal of International Relations. 1993. Vol. 1. No. 1.

11 See: Journal of International Affairs. 1994. Vol. 1. No. 1 journal too emphasized on both traditional and nontraditional aspects of security by providing analysis on Bangladesh's foreign relations with India and former Soviet Union along with highlighting conceptual issues relating to neoliberalism, the idea of Bangistan and South Asian issues ${ }^{12}$. The Asiatic Society of Bangladesh also publishes issues relating to Bangladesh, which often includes Bangladesh's foreign policy choices, constraints, determinants as well as domestic issues having international implications in its Journal of the Asiatic Society of Bangladesh (Humanities), which is currently running its 63 rd volume. Thus, the "international" for Bangladesh emerged as a combination of both traditional and non-traditional issues from the very beginning.

One notable line of research is Asian Survey's yearly publication on the state of Bangladesh since 1972, the very first issue of which was written by Rounaq Jahan [Jahan 1972]. Since then, Asian Survey publishes yearly review of Bangladesh that highlights domestic political, economic and social development and introduces the country for international audience. The writers include both Bangladeshi scholars living in Bangladesh and abroad and foreign scholars who have specialization on Bangladesh's politics. The latest issue on Bangladesh [Fair 2018], for example, is written by C. Christian Fair who is a known face in Bangladesh's academia by virtue of publishing researches on trends in violent extremism in Bangladesh.

In the 1970s and the 1980s, most of the research on Bangladesh's international relations was carried out by academics belonging to DUIR, in the Department of Political Science, DU and researchers of BILIA and BIISS. Notable publications of the first two decades emphasized on identifying challenges and directions with regard to Bangladesh's foreign relations. These studies generally branded Bangladesh as "weak" or "small" state due to its locational reality [Husain 1988]. Other issue areas included the region of South Asia, the relevance and future of SAARC, Bangladesh's relations with the superpowers and the Middle East. While this trend continued [Huq 1993], a new trend started when researchers in the 1990s emphasized on Bangladesh's success in the areas of development and governance. The identity

12 See: Journal of International Relations. 2005. Vol. 1. No. 1. 
of writers also pointedly diversified as a number of retired diplomats and government officials contributed in developing academic resources on Bangladesh's foreign policy and development challenges. The issues in the first decade of 2000 emphasized on economic diplomacy, along with traditional foreign policy issues and subregionalism in South Asia [Sabur, Kabir 2000]. The global trend in the rise of violent extremism also affected Bangladesh especially with the $8 / 21$ bombing in 62 out of 64 districts of the country in 2005. This added a new area of research - terrorism and violent extremism in Bangladesh and a number of books and articles were published on these issues [Sobhan 2008; Ahmed 2008].

The mass exodus of Rohingyas in Bangladesh since August 26, 2017, largest of its kind till date, did not escape the notice of Bangladeshi researchers. Research originating from Bangladesh thus addressed Rohingya issue by emphasizing its particular national characteristics. Bangladesh's foreign policy objective of "friendship with all, malice to none" — as set out by the founding father of the country Bangabandhu Sheikh Mujibar Rahman has determined a particular approach of foreign policy as well as research. It shows the early trend in Bangladesh's foreign policy that was guided by idealism - that foreign policy of Bangladesh must reflect the plight of the others. This was evident in Bangladesh's decision to open up the border and not to react to the provocations of Myanmar. Despite a dearth in resources, Bangladesh is hosting 1.2 million Rohingyas at present. Similarly, other distinct Bangladeshi characteristics can be found in the analysis of Bangladesh's manpower export and its implications on Bangladesh's relations with the Middle Eastern countries. This area of studies unfolds Bangladesh's specific concerns as manpower export is considered one of the major national resources of the country through which it earns highest source of foreign exchange. Bangladesh's prominent newspapers like The Daily Star, Dainik Protho Alo, Samakal, Dhaka Tribune, Bangla Tribune have emerged as another source of discussing and disseminating international issues. This has become possible due to active engagement of both the academic community and the diplomatic community to find a forum of interaction and disseminating views.

\section{Bangladesh Rise and Its Implications for the Study of IR}

The country has witnessed a new kind of diplomacy after Mr. Dan Mozena came to Bangladesh as US Ambassador in November, 2011 and served until 2015. Not only he visited all 64 districts of Bangladesh but also embraced and promoted Bangladeshi culture in a manner never been done by any diplomats before. While diplomats generally kept a cautious distance from the general populace, Mr. Mozena rather showed a new kind of diplomacy by embracing the people. This raised interest on international issues as well as towards academic IR to a significant level. The US embassy's increasing engagements with the DUIR, whether Mr. Mozena delivering lecture to the PGDIR program of DUIR in 2014 or students team meeting US Secretary of State Ms. Hillary Clinton in 2012 and Mr. John Kerry in 2016 during their visits to Bangladesh have influenced creating an appeal for learning about the US as well as international politics. The burgeoning number of academic departments, a good number of which were established in the current decade, shows how Bangladeshis are interested to learn IR as well as create its own imprints in international politics.

\section{References / Библиографический список}

Abdur Rahman, A.K.M. \& Kabir, M. (2018). Changing Global Dynamics: Bangladesh Foreign Policy. Dhaka: BIISS. Ahmed, I. (Eds.). (2008). Terrorism in the 21st Century: Bangladeshi Perspectives. Dhaka: The University Press Limited (UPL).

Ali Ashraf, A.S.M. (Eds.). (2016). Intelligence, National Security, and Foreign Policy: A South Asian Narrative. Dhaka: Bangladesh Institute of Law and International Affairs / Department of International Relations, University of Dhaka.

Asadullah, M.N., Savoia, A. \& Mahmud, W. (2014). Paths to Development: Is there a Bangladesh Surprise? World Development, 62, 138-154. DOI: https://doi.org/10.1016/j.worlddev.2014.05.013.

Brewster, D. (2014). Is India Losing Bay of Bengal to China? The Interpreter. The Lowy Institute. March 19. URL: http://www.lowyinterpreter.org/the-interpreter/india-losing-bay-bengal (accessed: 15.04. 2019).

Buchanan, A. \& Moore, M. (2003). Introduction: The Making and Unmaking of Boundaries. In: States, Nations, and Borders: the Ethics of Making Boundaries / Ed. by A. Buchanan, M. Moore. New York: Cambridge University Press.

Choudhury, D. (1992). Bangladesh's Foreign Policy Outlook: Regional and International Settings. In: Bangladesh, South Asia and the World / Ed. by E. Ahamed, A. Kalam. Dhaka: Academic Publishers. 
Fair, C.C. (2018). Bangladesh in 2018: Careening toward One-Woman Rule. Asian Survey, 59 (1), $124-132$.

Hassan, S. (1989). The India Factor in the Foreign Policy of Bangladesh. In: Issues and Challenges Facing Bangladesh Foreign Policy / Ed. by M.G. Kabir, S. Hassan. Dhaka: Bangladesh Society of International Studies.

Huq, M.S. (1993). Bangladesh in International Politics: The Dilemmas of the Weak State. Dhaka: The University Press Limited.

Husain, T. (1988). Domestic Inputs in Foreign Policy. In: Bangladesh: Global Politics. Vol. 3 / Ed. by S.R. Chakravaty, V. Narain. New Delhi: South Asian publishers.

Imam, S.H. (2014). Grasping Our Strategic Potential and Tapping It. The Daily Star, April 25.

Jahan, R. (1972). Bangladesh in 1972: Nation Building in a New State. Asian Survey, 13 (2), 199-210. DOI: $10.2307 / 2642736$.

Mahmud, W., Ahmed, S. \& Mahajan, S. (2008). Economic Reforms, Growth and Governance: the Political Economy Aspects of Bangladesh's Development Surprise. World Bank on behalf of the Commission on Growth and Development Working Paper, 22. Washington DC.

Miller, E.R. (2019). Indo-Pacific Strategy: Implications for the Region. In: Roundtable. BIPSS and The Daily Star.

Mishra, V. (2018). China Is Moving into the Indian Ocean. The National Interest, April 14. URL: https://nationalinterest.org/ feature/china-moving-the-indian-ocean-25380 (accessed: 15.04.2019).

Sabur, A.K.M.A. \& Kabir, M.H. (2000). Conflict Management and Sub-regional Co-operation in ASEAN: Relevance of SAARC. Dhaka: BIISS.

Sahoo, P. (2013). Economic Relations with Bangladesh: China's Ascent and India's Decline. South Asia Research, 33 (2), 123-139. DOI: https://doi.org/10.1177/0262728013487632.

Sobhan, F. (Eds.). (2008). Countering Terrorism in Bangladesh. Dhaka: The University Press Limited.

Yasmin, L. (2016). Bangladesh and the Great Powers. In: Handbook on Contemporary Bangladesh / Ed. by A. Riaz, Md. Sajjadur Rahman. London and New York: Routledge.

Zaman, R.U. \& Yasmin, L. (2014). The Rise of China and India: An Inevitable Confrontation at the Indian Ocean? In: Sino-South Asian Relations: Continuity and Change / Ed. by B. Md. Monoar Kabir. Chittagong: University of Chittagong.

Zaman, R.U. (2016). UN Peacekeeping Mission. In: Handbook on Contemporary Bangladesh / Ed. by A. Riaz, Md. Sajjadur Rahman. London and New York: Routledge.

Received: 10.05.2019

For citations: Yasmin, L. (2019). Development of International Relations at the Periphery: The Case of Bangladesh. Vestnik RUDN. International Relations, 19 (2), 247-255. DOI: 10.22363/2313-0660-2019-19-2-247-255.

About the author: Lailufar Yasmin - Professor at the Department of International Relations, University of Dhaka, Bangladesh (e-mail: lyasmin@du.ac.bd).

DOI: $10.22363 / 2313-0660-2019-19-2-247-255$

\section{Развитие международных отношений на периферии: пример Бангладеш}

\section{Л. Ясмин}

Университет Дакки, Дакка, Бангладеш

Международные отношения больше не рассматриваются в качестве учебной дисциплины, в которой говорится только о деятельности ведущих или великих держав. После преобладания традиционного государственно-центричного подхода к безопасности в годы холодной войны международные отношения прошли долгий путь, чтобы расширить свою тематику. Точно так же небольшие страны и их влияние на международную политику постепенно становятся важной областью международных исследований. Статья вносит свой вклад в изучение данного вопроса: автор анализирует растущее значение Бангладеш в мировой политике и то, как научная дисциплина о международных отношениях решает эту проблему. Он отслеживает историю изучения международных отношений в Бангладеш, а также постепенное расширение данной области исследований.

В статье рассматривается развитие международных отношений как академической дисциплины в Университете Дакки, Бангладеш, что постепенно привело к росту числа исследований международных отношений в других частях страны. Таким 
образом, автор заполняет пробел в понимании того, как и где происходило развитие исследований международных отношений в незападной стране. Также утверждается, что, несмотря на незначительные масштабы международных исследований в Бангладеш, именно они вызвали интерес к стране из-за меняющейся геостратегической значимости данного государства. Описывается растущее геополитическое значение Бангладеш, где великие державы стремятся получить влияние и стать частью развития государства. Именно в этом контексте изучение международных отношений в Бангладеш становится все более актуальным.

Ключевые слова: международные отношения, Бангладеш, изучение международных отношений, геостратегическое видение, университеты Бангладеш

Дата поступления статьи: 10.05.2019

Для цитирования: Yasmin L. Development of International Relations at the Periphery: The Case of Bangladesh // Вестник Российского университета дружбы народов. Серия: Международные отношения. 2019. Т. 19. № 2. $247-255$. DOI: $10.22363 / 2313-0660-2019-19-2-247-255$.

Сведения об авторе: Лаилуфар Ясмин - профессор кафедры международных отношений, Университет Дакки, Бангладеш (e-mail: lyasmin@du.ac.bd). 